\title{
MUMMIFIED BATS AT THE PAS
}

\author{
WALTER KRIVDA, Box 864, The Pas, Manitoba. R9A 1K8
}

Recently some students brought me six specimens of bats. They are dry and perfectly preserved. The students explained that they found the bats in a cottage that wasn't used for a whole summer. The very clean air at the lake and the dry environment of the cottage helped preserve the bats.

Usually to preserve any mammal specimen, one must skin it, treat the pelt and sometimes paint insecticides on the inside to prevent future attacks by museum pests such as common Bacon or Larder Beetles.
The specimens are solid. They are hard and dry like a board and have been saved as demonstration specimens in the writer's collection. The drying process was evidently gradual so that the complete structures of the ears are well preserved, as can be seen by inspection with a magnifying glass. The nose and nostrils are similarly in good condition. It is possible that the wide expanse of the bats' wings promoted the evaporation of body fluids and helped with the drying and production of bat mummies. Surely these are the first for the north country.

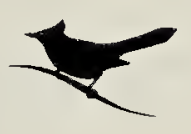

The water which softens us as it circulates through each cell has already been down every river and slept in every ocean. The blood of the land is the river of the body.

F. Lehrman. 1988. The Sacred Landscape. Celestial Arts, Berkeley, CA. 